\title{
XXXI. On the hydrate of the oil of laurel turpentine
}

\section{John Stenhouse Ph.D.}

To cite this article: John Stenhouse Ph.D. (1844) XXXI. On the hydrate of the oil of laurel turpentine , Philosophical Magazine Series 3, 25:165, 200-200, DOI: 10.1080/14786444408644969

To link to this article: http://dx.doi.org/10.1080/14786444408644969

曲 Published online: 30 Apr 2009.

Submit your article to this journal

Џll Article views: 2

Q View related articles $\sqsubset$ 


\section{[200]}

XXXI. On the Hydrate of the Oil of Laurel Turpentine. By John STenhouse, Ph.D.*

A FORMER communication contained a short account of a volatile oil called laurel oil of Guiana, said by Professor Christison to be obtained by incisions from a species of ocotea. It was found to consist of two isomeric oils, having the same composition, $\mathrm{C}_{5} \mathrm{H}_{4}$, as oil of turpentinet.

A quantity of this oil was mixed with some spirits of wine and a little nitric acid, exactly in the way recommended by M. Wiggers for procuring the hydrate of oil of turpentine. After it had stood for some months, a large portion of the oil was converted into a crystalline mass of a deep yellow colour. By dissolving it and repeatedly crystallizing it out of spirits of wine, it was readily procured in fine large rhombic prisms, which were perfectly white, and had neither taste or smell. These crystals melted at $257^{\circ} \mathrm{F}$, and when heated began to sublime at about $266^{\circ} \mathrm{F}$. When dried at $212^{\circ} \mathrm{F}$. they were subjected to analysis in the usual way.

I. 0.2615 grm. substance gave 0.662 of carbonic acid and 0.275 water.

II. $0.3068 \mathrm{grm}$. gave 0.780 of carbonic acid and 0.321 water.

\begin{tabular}{|c|c|c|c|}
\hline \multirow{5}{*}{$\begin{array}{l}\text { Carbon } \\
\text { Hydrogen } \\
\text { Oxygen }\end{array}$} & & & Calculated numbers. \\
\hline & I. & II. & At. $\quad$ Per cent. \\
\hline & $11 \cdot 68$ & $11 \cdot 62$ & 5 Hydrogen $=11 \cdot 44$ \\
\hline & $18 \cdot 33$ & $18 \cdot 08$ & 1 Oxygen $=18.37$ \\
\hline & 100.00 & $1 \overline{00 \cdot 00}$ & $\overline{100 \cdot 00}$ \\
\hline
\end{tabular}

It is evident from these analyses that the crystals of hydrated laurel oil are isomeric and isomorphous with those of the hydrates of the oils of turpentine and cedar. Their most probable formula is $\mathrm{C}_{5} \mathrm{H}_{4}+\mathrm{HO}$, or one atom oil and one atom water. This is rendered still more probable by the following experiment. When a portion of these crystals were distilled with anhydrous phosphoric acid they yielded a colourless oil, lighter than water, which had the same taste and smell as laurel oil, and appeared to be that oil regenerated. Unfortunately, from the small quantity of the crystals in my possession, I was unable to verify this by analysis.

The crystals also dissolved when gently heated in strong sulphuric acid, to which they gave a red colour. They evolved balsamic vapours which strongly reddened litmus. The addition of water precipitated the oil changed into a tenacious resin. 1844.

* Communicated by the Chemical Society; having been read April 1,

† See Phil. Mag. S. 3. vol. xx. p. 273. 